\title{
Meta-cognitive Skills and Strategies Application: How this Helps Learners in Mathematics Problem-solving
}

\author{
Simon Adjei Tachie ${ }^{1^{*}}$ \\ ${ }^{1}$ School of Mathematics, Natural Science and Technology Education, Bloemfontein, SOUTH AFRICA
}

Received 22 September 2017 • Revised 13 June 2018 • Accepted 14 August 2018

\begin{abstract}
Learners' problem-solving in mathematics is often problematic for both the learners and teachers and this needs to be addressed by applying relevant skills and strategies in the teaching and learning of mathematics. Meta-cognitive skills and strategies acquisition is vital for a learner's academic success and particularly in mathematics problem-solving. The paper investigates the relevance of learners' use of metacognitive skills and strategies in mathematics problem-solving. A qualitative approach was used, including a case-study design; observation and semi-structured interviews were used to collect data. Four rural schools, four mathematics teachers and four learners from different schools (one from each school) were selected for the study. Content analysis was used to analyze the data together with verbal quotes that supported themes that emerged. The aim was to obtain condensed and broad descriptions of the phenomena. The findings revealed that learners' use of metacognitive skills and strategies, such as task analysis, planning, monitoring, checking and reflection, self and group-monitoring skills, reading and writing skills, self-regulation skills (SR) and self-assessment (SA) helped them in mathematics problem-solving. The learners could also solve problems more easily through group discussions and thinking about their own thinking. Recommendations were made to benefit learners and further improve their use of meta-cognition for successful problem-solving.
\end{abstract}

Keywords: mathematics, meta-cognitive skills, self-regulation, self-assessment, teaching and learning, problem-solving

\section{INTRODUCTION}

Learners' poor mathematics performance in problem-solving in schools is both of national and international concern. Certainly researchers (Ahuja, 2006; Witterholt, Goedhart \& Suhre, 2016) argue that many mathematics educators lack adequate mathematical content knowledge hence their inability to raise their learners' performance to the highest level in mathematics problem-solving. This concern is often expressed in the small number of learners who enroll for mathematics in South Africa in the Further Education and Training (FET) phase owing to their prior inadequate achievement in mathematics (DoE, 2010; Maree, Olivier \& Swanepoel, 2004). Further afield, the mathematical background of students entering universities in countries such as Australia, the USA, the UK and Ireland has also been found to be a problem since it serves as an entry requirement for certain countries (Rylands \& Coady, 2008).

Learners throughout the world need to acquire different kinds of skills and strategies to help them solve their mathematics problems successfully (Witterholt et al., 2016; Lai 2011). Relevant literature has shown that in many countries such as Ghana, Botswana, Morocco, including South Africa, learners perform inadequately in mathematics as compared to their international counterparts (TIMSS $2003 \& 2007)$. This is attributed to a number of traditional approaches used in teaching and learning in schools (Feza-Piyose, 2012; Setati \& Barwell, 2008; Webb \& Austin 2009). It is thus a matter of urgency that learners be equipped with relevant knowledge skills and strategies as one way to address this problem. In the current development of the education system, creation of an

(C) 2019 by the authors; licensee Modestum Ltd., UK. This article is an open access article distributed under the terms and conditions of the Creative Commons Attribution License (http://creativecommons.org/licenses/by/4.0/). 囚TachieSA@ufs.ac.za simon.tachie@gmail.com (*Correspondence) 


\section{Contribution of this paper to the literature}

- The article extend the existing research on the application of the cognitive developmental, behavioural and social constructivist theories on the activities of the learners concerning skills acquisition.

- The findings of this study projects the meta-cognitive skills and strategies that empowers learners to organize their thought processes to refine their problem-solving skills in mathematics that are integral to achieving school learning outcomes.

- The findings affirm learners' use of monitoring and self-assessment strategies as tools to monitor their comprehension of a mathematical problem by checking their mistakes when using the problem-solving approach.

environment conducive to meta-cognitive skills and strategies application in problem-solving in learning is vitally important for the academic achievement of learners, especially in the rural areas of any country. This is because many rural schools are neglected in terms of human and material resources (Setati \& Barwell, 2008; Webb \& Austin, 2009). Such skills and strategies used by learners in problem-solving extend beyond the mathematics classroom and can include other areas of learning. While current bodies of literature focus on either skills or strategies applied in mathematics problem-solving and appropriate reflective activities, this paper looks at both and the effect thereof on the lives of rural school learners.

This qualitative study involved classroom observation and interviews held with four participating learners in senior-phase (Grades 7-9) mathematics classes and considered the relevance of their use of meta-cognitive skills and strategies in mathematics problem-solving which they exhibited. It demonstrates the necessity for learners to use meta-cognitive skills and strategies in problem-solving.

\section{Metacognitive Skills}

Metacognitive skills in most cases involves learners' individual skills such as self-regulation skills, selfassessment , monitoring and planning, and their ability to assess themselves whether the learning strategies they are using are effective to help solve the problem at hand (Mevarech \& Kramarski, 2003; Veenman, 2006). Learners use their metacognitive skills to assess many things in life in order to improve their learning abilities. For example, they use it to assess their level of achievement in learning, determine alternate strategies to solve a problem at hand, select the most appropriate strategy, and then re-assess the level of achievement in their lives. To improve learner's metacognitive skills in learning, metacognition teaching process is required (Amin \& Sukestiyarno, 2015). In most cases, learners should decide which strategy to use in solving a problem based on their attempts through the help of their teachers. According Kramarski, Mevarech and Aramaic (2002), the main elements of metacognition is either encouraging or teaching learners to work in small groups in order to reason mathematically, formulate and answer a series of questions or tasks metacognitively in problem-solving.

In South Africa today, education is moving towards a policy of inclusion whereby every learner has the right to quality and equal education (Engelbrecht, Green, Naicker \& Engelbrecht, 2004). The South African National Curriculum Statement (DoE, 2002) stipulates that social transformation in schools is vital in South Africa and therefore aims to ensure that there are equal opportunities for all learners by removing all artificial barriers to learning (DoE, 2003:2-4).

Researchers such as Christiansen, Howson and Otte (1984: 49) see the importance of mathematics as a foundation for advancement in technology by claiming that "living a normal life at the close of the twentieth century in many parts of the world requires everyday use of mathematics of some kind". Ebrahim (2010: 1) concurs with English (2007: 123-125) who says that "mathematics is a necessity for societal, technological and cultural growth" and that "skills such as analysing and transforming complex data sets, along with an understanding and application of school mathematics in general, serves as a basis for mathematical problem-solving in life". According to the Federation of Australian Scientific and Technological Societies, Science and Technology for Social, Environmental and Economic Benefit of Australia (2009), any country that has a population with a high level of mathematics skills as well as scientific literacy, helps to maximize scientific and technological innovation which ultimately enhances the standard of living and reduces poverty in communities. It also allows nations to be internationally competitive with regards to their economy, hence learners' need for the effective use of metacognitive application in problem-solving. Therefore, assisting learners to acquire metacognitive skills and strategies is worthwhile initiative that must be adopted by every country to improve skill acquisition of its own citizens for self-sustainability and development. 


\section{META-COGNITION AND ITS BENEFITS}

Flavell (1976) first introduced the word 'meta-cognition' in the United States of America. The term 'metacognition' refers to the individual's awareness and ability to think critically, that is, thinking about their own thinking, employing reflective judgment, consideration and control of his or her own cognitive processes and strategies (Flavell, 1976: 232). The concept 'meta-cognition' was introduced to assist both gifted and disabled learners with memory development and reflective thinking, especially in the area of literacy and problem-solving. Thereafter it spread worldwide (Flavell, 1976). Wilson (1998) concurs in that meta-cognition should be assessed within the mathematical arena to increase the quality thereof when being taught in order to enable learners to develop their thinking abilities regarding problem-solving. Panaoura and Philippou (2007) indicate that Flavell (1976) further distinguishes between three major categories of factors or variables in meta-cognition, namely: person, task and strategy, all of which exhibit meta-cognitive skills. According to them, the "person" category includes everything that a person believes about himself/herself in executing a task together with the assistance of other people as cognitive processors for self-regulation development (Panaoura \& Philippou, 2007). They go further to say that humans do not live in isolation but rather in communion and cooperation, and that each operates cognitively as an organism to acquire knowledge and skills through thinking about his/her own thinking for further development in problem-solving. Learners therefore need to work together through meta-cognition and use all the necessary regulation skills and strategies in order to solve the problem at hand.

Whitebread et al. (2009) expand on the above by stating that the "task" category in the form of reading and writing, concerns any observable information accessible to a person during a cognitive scheme for development of self, as well as emotional and motivational regulation skills development in problem-solving. It is believed that when learners embark on the implementation of writing skills, their understanding of the problem at hand moves to a higher level. They are therefore able to identify additional skills and strategies that can be used efficiently by them to solve the problem at hand, and further reflect on their thinking during the problem-solving process encountered in class (Knox, 2017). Performing different tasks at a particular time entails different mental operations coupled with developmental stages; this leads to the effective application of meta-cognitive skills and strategies through thinking about one's own thinking in order to affect the outcome of any intellectual undertaking (Whitebread et al., 2009).

Meta-cognition application enhances learners' skills and further promotes teachers' content knowledge through thinking about their own thinking in learning (Posthuma, 2011; Fischer, 1998). To achieve a particular goal one needs basic cognitive knowledge (Livingston, 1997). In this regard, the strategy category, as indicated by Panaoura and Philippou (2007), includes a great deal of knowledge that can be acquired, depending on what skills and strategies are likely to be effective in achieving set goals and depending on what sort of cognitive undertakings one engages when problem solving during learning.

For a better understanding of meta-cognitive application in learning skills and strategies that help to achieve the outcome of one's goal or problem, it is necessary to explain learning skills and strategies first as used in this study. 'Learning skills' refers to any skillful activities, methods or expertise that help learners in problem-solving whereas the term 'learning strategies' refers to "behaviours or actions which learners use to make mathematics learning in problem-solving more successful, self-directed and enjoyable" (Oxford, 1989: 235-239).

In Singapore, the mathematics curriculum has included meta-cognition as one of the five key components essential for the development of mathematical problem-solving (Yoong, 2002).

Dawson (2008: 3) states that "meta-cognitive strategies are usually conceptualized as an interrelated set of competencies for learning and thinking and include many of the skills required for active learning, critical thinking, reflective judgment, problem-solving, and decision making". In other words, learners who have well-developed meta-cognitive skills through thinking about their own thinking are better problem solvers, decision makers and critical thinkers, all of which improve their learning skills. Meta-cognition is therefore an important aspect of student learning, and the development of meta-cognitive skills and strategies gives students the ability to better organize their thought processes and to refine their thinking skills in problem-solving (Joseph 2010; Knox, 2017; Schraw \& Graham, 1997). Livingston (1997) maintains that basic cognitive knowledge is required to achieve a particular goal; it guides an individual to achieve a goal in a learning situation. Furthermore, the appropriate use of meta-cognitive skills/strategies helps individuals to gain knowledge and intellectual abilities that guide and direct intellectual processes in learning (Gok 2010; Knox, 2017; Lai 2011). It further assists learners not to struggle with communicating the steps taken to solve the problem at hand. They must further be able to explain why those steps are valid in executing the action when it comes to conceptual reasoning with mathematics or the problemsolving process.

When learners reflect on their own achievement through thinking about their own thinking, this can be regarded as an aspect of their higher-order reasoning and reflective questioning as an element of meta-cognition; both elements help improve their learning abilities or help develop their meta-cognitive abilities (Jagals, 2013; 


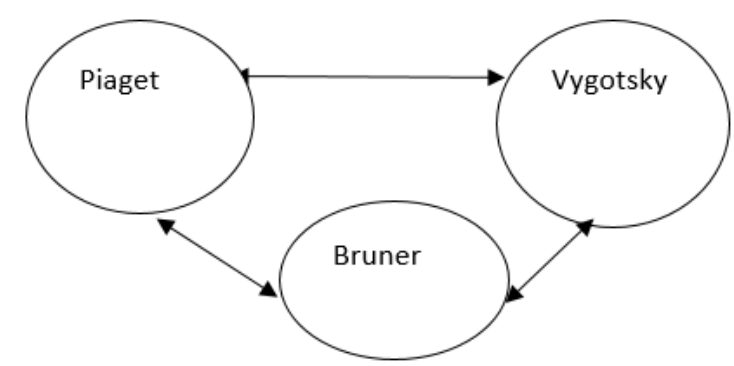

Figure 1. Constructivist approach to meta-cognition

Strawderman, 2010). Philosophers, such as Dewey (1998), refer to conscious reflective activities whereby learners conceptualize their knowledge and experiences through rethinking and evaluation of their efforts for a better outcome or improvement (Bormotova, 2010). It is against this background regarding the relevant use of metacognitive skills and strategies in mathematics problem-solving among rural school learners that the present study wanted to establish the impact of learners' meta-cognitive application on mathematics problem-solving.

\section{OBJECTIVE OF THE STUDY}

The present study sought to investigate the relevance of learners' use of meta-cognitive skills and strategies in problem-solving in four selected schools of the Eastern Cape Province. The objective of the study is to establish how learners use of meta-cognitive skills and strategies by rural schools learners assist them in mathematics problem-solving. The main research question addressed in this paper is: What is the role of these skills and strategies in the learners' mathematics problem-solving strategies?

\section{CONCEPTUAL THEORETICAL FRAMEWORK}

The concepts of meta-cognition and mathematics problem-solving have to be combined and framed by a reliable theory that supports and directs learners' learning of mathematics in the rural schools. In this regard, the three concepts that constitute the conceptual theoretical framework of this study include:

Cognitive Developmental theory (Piaget, 1973), Behavioural theory (Bruner, 1966) and Social Constructivism theory of learning (Vygotsky, 1978) are illustrated in Figure 1 which indicates their relationship.

A discussion below shows how each of these concepts focus on learners' use of meta-cognition in solving mathematical problems as well as the elucidation of the relationships between the concepts. The discussion further explains the empirical and theoretical knowledge that demonstrates the combination and interweaving of these theories as discussed below.

\section{Cognitive Developmental Theory}

The study is based on a theoretical framework regarding learners' use of meta-cognitive skills and strategies in solving mathematical problems in class, based on their actions, activities and methods used in teaching/learning in the rural schools of the Eastern Cape Province of South Africa. In this regard, the main theory guiding this study is the Cognitive Developmental theory of Piaget (Piaget, 1973), supported by the Behavioural theory (Bruner, 1966) and Vygotsky's Social Constructivism theory of learning (1978). These theories explains that if children are allowed to practice, and further engage in a series of practical activities and discourse, they will gain mastery and be in control of the tasks set before them. The application of these theories to an educational perspective focuses on the activities of the learner with regard to skills acquisition. For meta-cognition application to happen, learners are supposed to reach out to the higher levels of reflection of their actions through thinking about their own thinking as an example of meta-cognition in order to justify their use of meta-cognition in problem-solving (Bormotova, 2010). The development of meta-cognitive skills and strategies gives students the ability to better organize their thought processes and to refine their thinking skills in mathematics problem-solving, both of which are important to lifelong development of academic achievement (Knox, 2017; Schraw \& Graham, 1997). This therefore supports rural learners where there are lack of human and material resources at their disposal.

\section{Behavioural Theory}

Bruner (1966), a philosopher of learning, views the purpose of education as promoting and developing learners intellectually and socially, as well as developing moral growth of individuals' ability to construct knowledge for themselves in order to create a strong democratic society. He was mostly concerned with problem-solving 
situations, that is, how people think about their own thinking when faced with real and relevant life problems. His interest was based on discovery learning whereby learners mostly use their cognitive knowledge when faced with problems in life in order to develop themselves as people since learning is very important in the cognitive development of a child (Bruner 1966; Mokhaba 1993). This theory refers to how people think or reflect when faced with real-life problems in order to find a solution to the problem. In this regard, Dewey (1933:17) states that it is reflection "that emancipates us from merely impulsive and routine activity and enables us to direct our activities with foresight and to plan according to ends-in-view, or purposes of which we are aware. It enables us to act in deliberate and intentional fashion to know what we are about when we act. This means that when rural schools learners are developed with meta-cognitive skills and strategies, they will be self-motivated in finding solutions to their daily routine problem-solving activities at all times.

\section{Social Constructivism}

Henson (2004) states that constructivism is a theory that describes how learning occurs in a real-life situation. Vygotsky (1978) states that the key to understanding the nature of human consciousness in learning includes thinking, communication and interaction. In this regard, social constructivism is based on specific assumptions of reality, learning and knowledge (Kim 2001) and the way in which knowledge is constructed and applied spontaneously in problem-solving (Cooperstein \& Kocevar-Weidinger, 2004). Relevant literature substantiates the fact that a unique attribute of social constructivism is that learning and problem-solving are seen as the central, unavoidable part of the philosophy of mathematics (Ernest, 1998). Knowledge acquisition in life through successful learning is simply the outcome of mutual social interactions between people/learners in a social setting where diverse cultures, discourse and context are important factors in understanding each other (Kim, 2001). This helps learners to take responsibility for their own learning in order to solve life's problems successfully in a spontaneous manner (Cooperstein \& Kocevar-Weidinger, 2004; Posthuma et al., 2015). In the current dispensation, quality education involves mastering of specific knowledge, skills and strategies, and the development of the learner's abilities in problem-solving (Dolya, 2010). Social constructivism theory, in a real sense, helps us to understand how people learn and construct knowledge in social contexts to solve a problem, thus, they learn from each other and develop new ideas through thinking about their own thinking. Mathematics problem-solving therefore requires thinking in order to apply relevant skills and strategies for successful execution of the problem.

\section{METHODS}

\section{Research Design}

The research design adopted for this study was an exploratory qualitative research design. This is based on an interpretivist paradigm as it seems to fit the description of the purpose as well as the framework of this study (Nieuwenhuis in Maree 2007; Cecez-Kecmanovic, 2011). The sample comprised of four rural schools, four mathematics teachers and four learners for this study. Learners' efforts at sense-making and the relevance of using meta-cognitive skills and strategies were sought through observation and interviews, hence the exploratory design. In this study, skills and strategies used in solving the problem were observed and video-taped showing the spontaneous meta-cognitive actions applied and which pertained to solving the problem successfully based on the mathematical problems given to them by their teachers. These were checked and scrutinized carefully to enable the researcher to understand the social reality of meta-cognition as a phenomenon and to interpret the reasons for participants' actions and thoughts about solving mathematical problems meta-cognitively. The interpretation and explanations of the qualitative data obtained in this study were of a social constructivist nature since learners undertook a number of activities in mathematical problem-solving on integers.

\section{Sampled Participants}

In this study, 4 teachers; males $=2$ and females=2, and 4 learners; boys $=2$ and girls $=2$ were purposefully selected and were observed during teachers' teaching and learners' learning of mathematics in their classrooms. The selected participants comprised only senior phase (grades 7-9) mathematics educators as well as learners in the rural schools of Lusikisiki District. Four schools were also selected purposely based on their geographical location however, considered to be amongst the best performing schools in the district. The schools were selected based on cluster sampling method. Human and material resources in the selected schools as well as the proficiency of the teachers were taken into consideration during sampling. 


\section{Instruments}

Two instruments were used to collect data in two stages. These consisted of classroom observations and individual, semi-structured interviews. A pilot study was first conducted to check the usability of the instrument before the main study.

\section{Procedures}

The selected teachers were not the target of this study but to assist the researcher achieve his objective of the study by observing learners on how they solve mathematics problems using meta-cognitive skills and strategies when the teachers were teaching. The researcher further observed how the use of meta-cognitive skills and strategies by the learners assisted them solve mathematics problems amicably given to them by their teachers during teaching and learning in class. For example, during class intervention on the number line, their teachers directed them (learners) on how to plan either individually or collaboratively right from the beginning of problemsolving and assist their colleagues in drawing or listing of some concepts that helped in solving the problem without difficulties. Teachers called some learners to do some number line illustrations on the chalkboard about how they solve problems on integers without the help of their teachers. Learners were first observed in their various classrooms during teachers' lesson presentations to check the above stated points on how they solve problems in all those selected schools in this study. They were observed in order to check the way in which they used metacognition in their mathematics problems on integers. Learners did many illustrations on the board to assist their colleagues understand how they could easily solve problems on integers through planning, monitoring of their procedures, follow-up questions and self-reflection. In the interview session (stage 2), participants answered semistructured questions regarding their attitude towards mathematics problem-solving before and after intervention strategies. This was done in order to explore the mathematics confidence that learners develop based on their experience(s) with mathematics as well as actions and strategies employed to solve mathematics problems. Three types of qualitative questions were asked: main questions, probes (or exploring questions) and follow-up questions (Bormotova, 2010; Jagals, 2013). The research assistant explained these questions to the learners in their mother where necessary. In this regard, the following semi-structured interview questions were asked:

1. What steps do you as a learner usually take to understand a concept or a problem spontaneously if you did not understand it during lesson presentation by your teacher?

2. In what ways does your questioning style with peers help you in mathematics problem-solving?

3. How does the group-discussion/cooperative learning among you as learners, spontaneously contribute to meta-cognition application in mathematics problem-solving in class?

4. How does the use of learning aids support your understanding of mathematics problems?

5. What kind kind of meta-cognitive skills and strategies do you use in mathematics problem-solving?

6. What is the role of these meta-cognitive skills and strategies in your mathematics problem-solving strategies?

\section{Ethical Issues}

Permission was first obtained from the Eastern Cape Department of Basic Education and the relevant authorities of the participating districts, schools and participants before the study was conducted. Consent forms were given to the adult learners as well as the parents of those who were under eighteen years of age in order to document formally their consent to participate in the study. In this study, confidentiality was also ensured by asking participants not to mention their names during interviews or write their names on any document during data collection.

\section{Data Analysis}

Data were analysed through grouping of responses into categories or themes. Through open coding, the researcher identified categories and themes on similar content that learners should know about, understand and be able to apply (Nieuwenhuis, 2007). For example: Learning must start from what we know to unknown, Teaching and learning of mathematics must relate to our environment in our experience, Learners must be involved in lesson presentations, Discussions always help us in our problem-solving, Use concrete objects when teaching so that they can play with anytime they are playing, Teachers must try to make your lessons practical. 


\section{FINDINGS}

Learners indicated many activities that they undertook on their own and with the help of their teachers as metacognitive skills and strategies that helped them to understand mathematics concepts easily as discussed below. This further indicated the importance of the use of meta-cognition for learners in schools. Some of the activities included: Thinking aloud when solving problems individually or in groups, mmonitoring their comprehension when solving problems in group discussions; developing reflective habits when solving problems; using the internet to search for information for their assignments; thinking about their own thinking and monitoring their comprehension when solving problems; always providing solutions to problems themselves in the first place and later showing the results to other people to check the steps or procedure as well as the answers to see whether they were correct or wrong; but if their answers were wrong, these learners always explained to them by showing them where they had made a mistake or mistakes. Here are some of the problem-solving questions: For examples "If the product of 6 integers is negative, at most how many of the integers can be negative?"; Let $a, b$ and $c$ be positive integers. If $a+b=4, b+c=8$ and $c+a=6$. What is the value of $a \times b \times c$ ?

The learners indicated that they had to think very deep before they could get answers to the above problems. For instance, in example 1, some learners indicated that they took any five positive numbers and a negative number. Moreover, they had to check the number of times the negative number when multiplied by a positive number, gives an answer to a negative number. They added that they ended up getting five negative numbers as the answer. Furthermore, they did the same trial-and-error activities in example two before they got their answers to be $(a=1$; $b=3$ and $c=5$ ) and therefore, $a \times b \times c$ gives an answer to be 15 . This, they said, normally helped them areat deal to understand concepts or ways of solving mathematics problems. They further indicated that they had group discussions to assist them in understanding the problem at hand. They also indicated that they usually solicited different opinions and demonstrations which were then monitored by either their teachers in class or any of their seniors in high schools who understood what they are attempting. This, they said, helped them to develop an ongoing interest in learning mathematics. This was evident in the asking of questions that developed their understanding of mathematics. They also indicated that the use of meta-cognitive skills and strategies such as planning, self-monitoring, reflection and self-monitoring of problem solving steps helped them immensely to understand many mathematical concepts which they did not know before as indicated in the extract below.

The following excerpt from a learner's response to supports the above statement:

Learner 2:

If we can't remember the formula, in our group we divide ourselves into two then one will try this method and the other one will try another method even if it is wrong. So we go on trying until we get the correct answer and that group will explain to the rest how they did it. We all go back to check the method, the steps and everything to see and if we are satisfy, we use it to check the other group that is wrong to see where the the mistake is and later we explain to the whole group if it our turn.

In the current study, it could be inferred that individual learners in the Senior Phase used meta-cognitive skills and strategies repeatedly to solve mathematical problems. Evidence supporting this statement includes: Learners going to the chalk-board to do additions and subtractions of integers using illustrations and learning aids; learners forming groups to discuss how to solve the problem among themselves, including the procedure to solve the problem and with some of the quicker learners assisting slower learners, and learners challenging others on the procedure(s) used to solve the problem at hand spontaneously. From the observations, learners in some cases, who finished their work earlier, could go forward to share their ideas with lower learners.

The findings from the learners' direct responses concerning monitoring and evaluation strategies used in problem-solving in this study revealed that learners actually did use monitoring and self-assessment strategies to monitor their comprehension of a problem through checking all their initial mistakes they committed during problem-solving. They then made some relevant changes in their discussions, as verbally indicated in the statement made above. The following examples of responses from two learners support the above statement:

Learner 1:

That is, when we we we are doing any activity in class as a group, we we try the first method to to to work the problem but if if we we we don't get the correct answer, we nor nor normally asked ourselves questions like: What is the problem? What is iwrong with this method? What else did we have to do that we did not do initially? What can we do again? Can we go back and check the ways we did it or the processes to see where the mistake is? So we stop and go back to check our mistakes. If there are no mistakes, we we we just say let us change our method or use different approach or methods to see whether we will get the answer. When we do that and get the correct answer by chance, then we say 
you see, this where we made the mistake so we correct it and we always remember and use that formula for similar activities.

An interesting issue observed is that one learner indicated that she usually became discouraged when, on one occasion, her teacher told the class to go and search for information by themselves; she found it difficult to obtain the information without the necessary skills and strategies.

One learner had this to say:

Given an opportunity to explore is is something that helps you as a learners who is studying because it helps you to get answers to a problem at hand without fear or favour from anybody. This helps you to be independent in finding a solution to a problem and this helps you more to develop or improve or acquire more skills and strategies of solving problems which, at the end of the day, improve your thinking ability in learning. I think if all learners will be allowed to to to do that, I think it will improve our cognitive ability or skills of finding solutions to a problem so the government should encourage that in all schools rather than teachers spoon feeding learners in classrooms.

\section{DISCUSSION}

\section{Meta-cognitive Skills and Strategies Application Help Learners in Mathematics Problem- solving}

There is a prominent body of empirical and theoretical knowledge that demonstrates the positive outcomes of a constructivist approach to meta-cognition development among rural learners in the classroom (such as Bruner 1966; Piaget 1973; Vygotsky 1978). Figure 1 illustrates Social Constructivism as the foundation for the conceptual theoretical framework of this study. This serves as the epistemological lens for the conceptual theoretical framework through which the relevance of rural schools learners' use of meta-cognition in mathematical problemsolving is exhibited. In the current education system in South Africa, mathematics education ideologies, as demonstrated in some teaching and learning materials, requires every learner to acquire knowledge through thinking processes, required to accomplish a task successfully. This is what the Department of Basic Education (DBE) expects of learners with regard to problem-solving (DBE, 2011a) hence the combination of the above concepts. Constructivist theory of learning enables learners to actively construct knowledge within and by leaders as life-long learners. The use metacognitive skills and strategies enables learners to construct active long-life knowledge as indicated in the study. Thus, knowledge that not only helps learners to have control over the mathematics content but how to conceptualize the idea of solving mathematics problems. Constructivist views on learning require learners to learn enough to seek their own understanding, insights and meaning-making which are worthwhile if done through the questioning of their own knowledge and new discoveries in their learning environment; they think about their own thinking in problem-solving since knowledge cannot be told but only gained through experiences (Cooperstein \& Kocevar-Weidinger, 2004). For learners to solve problems metacognitively, they need to place greater emphasis on thinking about their own thinking (through discussion and argumentation) which then usually leads to spontaneous discovery of new knowledge in life. Cognitive research psychologists such as Piaget (1973), Vygotsky (1978) and Bruner (1966) state that learners try to make sense of the world by relying on their pre-existing schemas. Learning is therefore supported by social interaction with peers and teachers through real-world experiences. Teachers of mathematics should always encourage their learners to embark on activities that make use of real objects that project spontaneous understanding of ideas as teaching/learning materials when teaching. Furthermore, learners should be encouraged to make use of available materials in their environment that add value to their creative thinking when solving mathematical problems as real objects portray more meaningful understanding than abstract ones (Bruner, 1966). All these theories and concepts (discussed above) and how they are related to each other for the conceptualisation of this study are indicated in Figure 1 under the conceptual framework. These theories revolve around three main domains - the intellectual, social and psychological, all of which help in the acquisition of meta-cognitive skills and strategies (Jagals, 2013; Strawderman, 2010). This is achieved through logical reflection and systematic thinking about their own thinking.

As the learner develops meta-cognitively, his/her knowledge starts to influence the way he/she thinks about his/her own thinking and this helps in solving word problems (Bruner, 1966). When a child can think beyond images, any information at his/her disposal can now be categorised, summarised and manipulated in any way to arrive at the best solution. The study revealed that learners' use of meta-cognitive skills and strategies in problemsolving is important in their lives since it helps them (learners) to think aloud when solving problems using various relevant skills and strategies without at times the help of teachers in problem-solving. In this regard, skills such as task analysis, planning, monitoring, checking and reflection, self-regulation skills (SR) and self-assessment (SA) 
were identified in learners during observation (Kayashima \& Inaba, 2014; Mevarech \& Kramarski, 2003; Veenman, 2006).

Bruner's theory generally addresses itself to the current study in the sense that there is a need for all learners to think about their own thinking logically and systematically in order to solve life's mathematical problems at hand by themselves without "spoon feeding" but through the help of anyone else where necessary. This is what metacognition is all about. With this in mind, this study looked at learners' mathematics problem-solving. Through this, learners used meta-cognitive skills and strategies spontaneously in solving mathematical problems through the help of their questioning style, group discourse, thinking about their own thinking and monitoring their comprehension as supported by some researchers (Example, Sepeng, 2010; Flavell, 1976; Johnson \& Kritsonis, 2006). Bruner contends the learner needs to use abstract symbols to represent reality in learning and spontaneous creative thinking, both of which pave the way for meta-cognition application.

In actual fact, Bruner's work has established itself in learning through participation and discovery (Bruner \& Haste, 1987). Children learn mathematics best by performing a series of activities themselves spontaneously, hence this theory. From this, Bruner claims that people learn better through interaction and exercise of communication, practical activities, reading and writing skills and that the role of the teacher is to create a situation where the learners can compile their own interpretations by using the interpretation and ideas of others around them to spontaneously solve problems successfully. It is agreed that practical activities and thinking about their own thinking in problem-solving activities helped them to understand their teachers' lessons better during classroom observation by sharing ideas as supported by some researchers (example, Flavell, 1976; Goos, 2004; White, 2003). This was because the fact that the input regarding the skills, the processes when using the skills and the output of the skills used by the learners in executing a solution to a problem were visible to the observers in the classroom during intervention (Kayashima \& Inaba, 2014). Such skills included self-regulation skills in problem-solving through observational learning, peer-assessment and evaluation skills in checking one another's planning activities to solve a problem at hand. For example, learners indicated that when they were performing any activity in class as a group, they first tried one method in order to work out the problem but if that method did not work, they normally asked themselves the following questions: What is the problem? What is wrong with this method? What can we do that we did not initially do? Can we go back and check our processes to see where the mistake was? They said they would then stop and go back to check their mistakes until they had the correct method that would lead them to the correct answer spontaneously. For self-assessment skills, learners constantly checked their own procedures (planning, actions, monitoring of actions and assessment of the actions) used in executing a problem. Learners also reflected on their procedures used during problem-solving and that enabled them to adjust their skills and strategies where necessary so as to arrive at a better conclusion when tackling a problem.

The study revealed that learners actually did use monitoring and self-assessment strategies to monitor their comprehension of a problem through checking all their mistakes made initially; they then made some changes to that effect in their discussions as verbally indicated in the results section above.

Learners who master meta-cognitive regulation skills can assist their peers by probing their regulatory skills such as reflection on planning before solving a problem (Muis, 2008). This helps them make effective use of procedures from the action-list in solving any mathematics problem they encounter in life. Some learners in this study planned their approach to problem-solving collaboratively or individually from the start by drawing, labelling, identifying and completing information on number lines they were taught by their teachers during the intervention in order to help them (learners) re-channel any form of worrisome and anxious thoughts they experienced in their minds (Bormotova, 2010). In the same vein, learners indicated that after they had tried some methods which did not initially solve the problem they were attempting, they would stick to the trial-and-error method until they had finally solved the problem. At this point, learners were able to observe their group leader's problem-solving procedures in a group discussion and therefore used their own skills by recalling how to solve similar or different problems on the chalkboard.

\section{CONCLUSION}

From the findings of this study, it can be concluded that Senior Phase rural school learners were able to use meta-cognitive skills and strategies which helped them in their mathematics problem-solving towards a better understanding of mathematics. For example, learners could use meta-cognitive regulation such as reflection for the planning and monitoring of their procedures and assessment in order to plan for ways to solve their tasks, and for group-work problems they face daily or when given to them by their teachers. In employing these, learners had an opportunity to express their feelings through problem-solving.

The availability and appropriateness of the application of instruction methods, skills knowledge and strategies used in solving a problem determines the degree of success learners attain in problem-solving. The use of reflection, planning and evaluation, as outlined in the literature review of this study, assists learners to acquire and apply 
meta-cognitive skills and strategies spontaneously in mathematics problem-solving. Learners should be exposed to more effective classroom mathematics demonstrations, discussions, argumentations, challenges, meta-cognitive regulation (such as reflection and hands-on teaching and learning techniques) at all times in order to develop their meta-cognitive abilities spontaneously and at the highest level in problem-solving.

\section{RECOMMENDATIONS}

The following are the recommendations arrived at after the above in-depth analysis of the findings of the empirical study. These recommendations cover a number of topics included in this study; recommendations range from administrative to teaching/learning issues and general organization of the school environment. The researcher hopes that the results of this empirical study can be used by the Department of Education, especially curriculum planners, in the planning of future General Education and Training (GET) band programmes for both rural and urban schools. In fact, further research should explore lesson study as a model, and other related models recommended through the literature reviewed for the teaching and learning of mathematics for learners' improvement in problem-solving at the GET band level. Learners should also make effective use of meta-cognitive skills and strategies (planning, monitoring, self-regulation, self-assessment) in almost all learning areas in order to be competent and to have an understanding of teaching and learning.

The findings of this study should provide insights for individuals and groups who strive to empower mathematics teachers in both the rural and urban areas, with innovative skills and strategies as well as effective pedagogies to familiarize themselves with the use of meta-cognitive skills and strategies in problem-solving.

\section{REFERENCES}

Ahuja, O. P. (2006). World-class high quality mathematics education for all K-12 American students. The Montana Mathematics Enthusiast, 3(2), 223-248.

Amin, I., \& Sukestiyarno, Y. L. (2015). Analysis metacognitive skills on learning mathematics in high school. International journal education and research, 3(3).

Ataman, A., \& Özsoy, G. (2009). The effect of meta-cognitive strategy training on mathematical problem solving achievement. International Electronic Journal of Elementary Education, 1(2), 67-82.

Bormotova, L. S. (2010). A qualitative study of meta-cognitive reflection: the beliefs, attitudes and reflective practices of developing professional educators (PhD Dissertation). Indiana University of Pennsylvania.

Bruner, J. S. (1966). Toward a theory of instruction. Cambridge, MA: Harvard University Press.

Bruner, J. S., \& Haste, H. (Ed.). (1987). Making sense: The child's construction of the world. New York: Methuen.

Cecez-Kecmanovic, D. (2011). 'On Methods, Methodologies and How They Matter', in Proceedings of the 19th European Conference on Information Systems (ECIS 2011), Association for Information Systems, USA, presented at 19th European Conference on Information Systems (ECIS 2011), Helsinki, Finland, June 9-11, 2011, http://aisel.aisnet.org/ecis2011/233.

Christiansen, B., Howson, A. G., \& Otte, M. 1984. Perspectives on mathematics education. Dordrecht: D. Reidel.

Cooperstein, S. E., \& Kocevar-Weidinger, E. (2004). Beyond active learning: A constructivist approach to learning. Reference Services Review, 32(2), 141-148. https:// doi.org/10.1108/00907320410537658

Coskun, A. (2010). The effect of meta-cognitive strategy trading on the listening performance of beginner students. Novitas-ROYAL (Research on Youth and Language), 4(1), 35-50.

Department of Basic Education (DBE). (2011a). Curriculum and Assessment Policy Statement (CAPS) Grades 1-3 Mathematics. Pretoria. $\quad$ Retrieved on 4 August 2014 from http:/ / www.education.gov.za/LinkClick.aspx?fileticket=ehGEpQZXz7M\%3d\&tabid=671\&mid=1880

Department of Education (DoE). (2002). Draft education for all status report 2002. South Africa.

Department of Education (DoE). (2003). Revised National Curriculum Statement grade R-9 (schools) Mathematics. Sol Plaatje House. Pretoria: Government Printer.

Department of Education (DoE). (2010). Curriculum and Assessment Policy Statement. Grade 10-12 Mathematics. Pretoria: Government Printer.

Dewey, J. (1933). How we think: a statement of the relation of reflective thinking to the educative process. Boston: Heath.

Dewey, J. (1998). How we think: A restatement of the relation of reflective thinking to the education process. Boston: Houghton Mifflin.

Dolya, G. (2010). Vygotsky in action in the early years. The 'key to learning' curriculum. London: Routledge. 
Ebrahim, A. (2010). Mathscitech. Retrieved on 23 April 2012 from http://mathscitech.org/papers/ebrahim-whatis-mathematics.pdf

Engelbrecht, P., Green, L., Naicker, S., \& Engelbrecht, L. (2004). Inclusive Education in Action in South Africa. Pretoria: Van Schaik.

English, L. D. (2007). Cognitive psychology and Mathematics education: reflections on the past and future. The Montana Mathematics Enthusiast, 4(2), 119-126.

Ernest, P. (1998). Social constructivism as a philosophy of mathematics. Albany: State University of New York Press.

Feza-Piyose, N. (2012). Language: A cultural capital for conceptualizing mathematics knowledge. International Electronic Journal of Mathematics Education, 7(2), 62-79.

Fischer, G. (1998). "Making Learning a Part of Life-Beyond the 'Gift-Wrapping' Approach of Technology." In P. Alheit, \& E. Kammler (Eds.), Lifelong Learning and Its Impact on Social and Regional Development, Donat Verlag, Bremen, pp. 435-462.

Flavell, J. H. (1976). Meta-cognition and cognitive monitoring: a new area of cognitive-development inquiry. American Psychologist, 34, 906-911. https:/ / doi.org/10.1037/0003-066X.34.10.906

Gningue, S. M., Peach, R., \& Schroder, B. (2013). Developing Effective Mathematics Teaching: Assessing Content and Pedagogical Knowledge, Student-Centered Teaching, and Student Engagement.

Gok, T. (2010). The general assessment of problem solving processes in physics education. Eurasian Journal of Physics and Chemistry Education, 2(2), 110-122.

Goos, M. (2004). Learning mathematics a classroom community of inquiry. Journal for Research in Mathematics Education, 35, 258-291. https:/ / doi.org/10.2307/30034810

Henson, K. T. (2004). Constructivist teaching strategies for diverse middle-level classroom. Boston: Pearson.

Jagals, D. (2013). Dissertation submitted for the degree Magister Education is in the Faculty of Educational Sciences at the North-West University Potchefstroom Campus (Unpublished dissertation).

Johnson, C. J., \& Kritsonis, W. (2006). A national dilemma: African American student's underrepresented in advanced mathematics courses. Doctoral Forum: National Journal for Publishing and Mentoring Doctoral Student Research, 20(3), 7.

Joseph, N. (2010). Metacognition needed: Teaching middle and high school students to develop strategic learning skills. Preventing School Failure: Alternative Education for Children and Youth, 54(2), 99-103. https:/ / doi.org/10.1080/10459880903217770

Kayashima, M., \& Inaba, A. (2014). The Model of Meta-cognitive Skills and How to Facilitate Development of the Skill. Retrieved on 7 August 2014 from https://www.nikubook.com/read-file/the-model-ofmetacognitive-skill-and-how-to-facilitate-development-pdf-5882737/

Kim, B. (2001). Social Constructivism. In M Orey (ed). Emerging perspectives on learning, teaching, and technology. Retrieved on 11 May 2013 from http:/ / epltt.coe.uga.edu/index.php?title=Social_Constructivism

Knox, H. (2017). Using Writing Strategies in Math to Increase Metacognitive Skills for the Gifted Learner. Gifted Child Today, 40(1), 43-47. https:/ / doi.org/10.1177/1076217516675904

Kramarski, B., \& Mevarech, Z. R. (2003). Enhancing mathematical reasoning in the classroom: The effects of cooperative learning and metacognitive training. American Educational Research Journal, 40(1), 281-310. https:// doi.org/10.3102/00028312040001281

Lai, E. R. (2011). Meta-cognition: A literature review. Retrieved on 15 October 2011 from http:/ / www.pearsonassessments.com/research

Lerman, S. (2001). Cultural, Discursive Psychology: A sociocultural approach to studying the teaching and learning of mathematics. Educational Studies in Mathematics, 46, 87-113. https:/ / doi.org/10.1023/ A:1014031004832

Livingston, J. A. (1997). Metacognition: An overview. Retrieved on 6 April 2010 from http://www.gse.buffalo.edu/fas/shuell/cep564/Metacog.htm

Maree, J. G., Olivier, E. C., \& Swanepoel, A. C. (2004). Die senior Harmony Suid-Afrikaanse Wiskunde-olimpiade: 'n analise van die resultate van die senior groep, tweede rondte. SA Tydskrif vir Natuurwetenskap en Tegnologie, 23(3), 52-60. https: / / doi.org/10.4102/ satnt.v23i3.193

Mayaba, N. (2009). The effect of a scientific literacy strategy on grade 6 and 7 learners general literacy skills (Unpublished MEd dissertation). Port Elizabeth: Nelson Mandela Metropolitan University.

Mokhaba, M. B. (1993). The application of the activity principle in mathematics teaching - A strategy for teacher training (Unpublished PhD Thesis). Pretoria: University of South Africa. 
Muis, K. R. (2008). Epistemic profiles and self-regulated learning: Examining relations in the context of mathematics problem solving. Educational Psychology, 33, 177-208.

Nieuwenhuis, J. (2007). Introducing qualitative research. In Maree, K. ed., First steps in research. Pretoria: Van Schaik.

Oxford English Dictionary. (1989). Oxford University Press.

Panaoura, A., \& Philippou, G. (2007). The developmental change of young pupils' metacognitive ability in mathematics in relation to their cognitive abilities. Cognitive Development, 22, 149-164. https:// doi.org/10.1016/j.cogdev.2006.08.004

Piaget, J. (1973). The child and reality: Problems of genetic psychology. New York: Grossman

Posthuma, A. (2011). The nature of mathematics teachers' reflective practice (Unpublished Thesis), University of Pretoria.

Posthuma, B., Human, A., \& Van der Walt, A. (2015). International comparisons of Foundation Phase number domain mathematics knowledge and practice standards. South African Journal of Education, 35(1), 1-13.

Rylands, L. J., \& Coady, C. (2008). Performance of students with week mathematics in first-year mathematics and science. International journal of mathematics education in Science and Technology, 40(6), 741-753. https:/ / doi.org/10.1080/00207390902914130

Schraw, G., \& Graham, T. (1997). Helping gifted students develop metacognitive awareness. Roeper Review, 20, 4-8. https://doi.org/10.1080/02783199709553842

Sepeng, J. P. (2010). Grade 9 Second-Language Learners in Township Schools: Issues of Language and Mathematics when solving word problems (Unpublished Thesis). Port Elizabeth: Nelson Mandela Metropolitan University.

Setati, M., \& Barwell, R. (2008). Making mathematics accessible for multilingual learners. Pythagoras, 67, 2-4. https://doi.org/10.4102/pythagoras.v0i67.68

Strawderman, V. W. (2010). Mathematics anxiety model. Retrieved on 5 Octover 2010 from http://www.mathgoodies.com/articles/math anxiety model.html

Van Oers, B. (2001). Educational forms of initiation in mathematical culture. Educational Studies in Mathematics, 46, 59-85. https:/ / doi.org/10.1023/ A:1014031507535

Veenman, M. V. J. (2006). The role of intellectual and metacognitive skills in math problem-solving. In A. Desoete \& M. V. J. Veenman (Eds.), Metacognition in mathematics education. New York: Nova Science Publishers.

Veenman, M., Van Hout-Wolters, B., \& Afflerbach, P. (2006). Metacognition and learning: conceptual and methodological considerations. Metacognition and Learning, 1(1), 3-14. https:/ / doi.org/10.1007/s11409-0066893-0

Vygotsky, L. S. (1978). Mind in Society: The Development of Higher Psychological Processes. Cambridge, MA: Harvard University Press.

Webb, L., \& Webb, P. (2008a). Introducing Discussion into Multilingual Mathematics Classrooms: An Issue of Code Switching. Pythagoras: Journal of the Association for Mathematics Education of South Africa, 67, 26-32. https://doi.org/10.4102/pythagoras.v0i67.71

Webb, P., \& Austin, P. (2009). The family maths programme: parents' perceptions of what influences their engagement, enjoyment and confidence within a complex learning community. Education as Change, 13(1), 27-44. https:/ / doi.org/10.1080/16823200902933438

White, D. (2003). Promoting productive mathematical classroom discourse. Journal of Mathematical Behavior, 22, 3753. https:/ / doi.org/10.1016/S0732-3123(03)00003-8

Whitebread, D., Coltman, P., Pasternak, D. P., Sangster, C., Grau, V., Bingham, S., Almeqdad, Q., \& Demetriou, D. (2009). The development of two observational tools for assessing metacognition and self-regulated learning in young children. Metacognition and Learning, 4(1), 63-85. https:/ / doi.org/10.1007/s11409-008-9033-1

Witterholt, M., Goedhart, M., \& Suhre, C. (2016). The impact of peer collaboration on teachers' practical knowledge. European Journal of Teacher Education, 39(1), 126-1243. https:/ / doi.org/10.1080/02619768.2015.1109624

Yoong, W. K., (2002). Helping Your Students to Become Metacognitive in Mathematics: A Decade Later. Mathematics Newsletter, 12(5).

Zimmerman, B. J. (2000). Attaining self-regulation: a social cognitive perspective. In Boekarts, M., Pintrich, P. R., \& Zeidner, M. (Eds.). Handbook of Self-regulation. San Diego, CA: Academic Press. https:/ / doi.org/10.1016/B978-012109890-2/50031-7

\section{http://www.ejmste.com}

